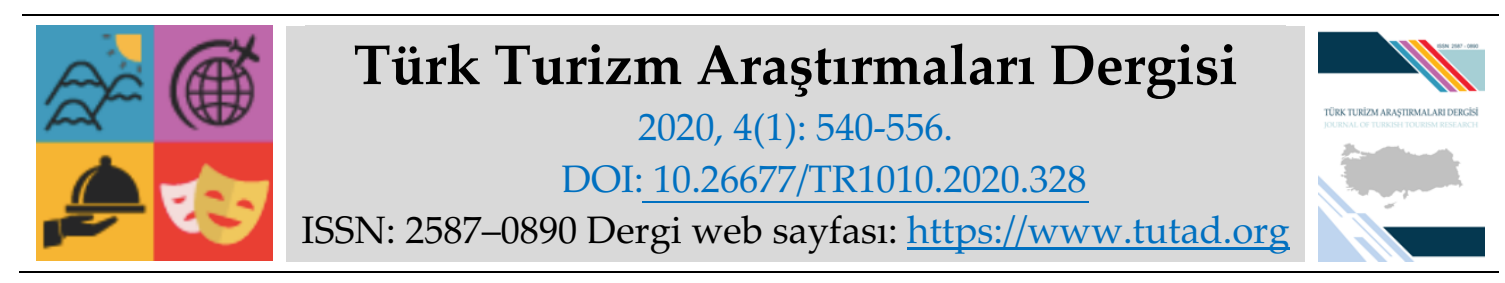

ARASTIRMA MAKALESI

\title{
Turizmde Gelişmenin, Yöre Halkı Üzerinde Oluşturduğu Toplumsal ve Kültürel Etkilerin Araştırılması: Kastamonu Örneği
}

Dr. Muharrem AVCI, Kastamonu Üniversitesi, Turizm Fakültesi, Kastamonu, e-posta: mavci@kastamonu.edu.tr

ORCID: https://orcid.org/0000-0002-0264-1181

\section{Öz}

Bu çalışma; toplumsal ve kültürel etkilerin henüz turizmde genç bir yöre olan Kastamonu destinasyonunda nasıl oluşmakta olduğunu ve yerli halkın bu konuya yönelik bakış açılarını belirlemeye yönelik hazırlanmış nicel bir araştırmadır. Araştırmada amaca ve içeriğe uygun olarak hazırlanmış bir anket çalışması kullanılmıştır. Bu kapsamda araştırma değişkenleri; "turizmin ahlaki ve kültürel değerleri tahrip ederek toplumsal hayatı olumsuz yönde etkilediği" ile "turizm, farklı toplumları temsil eden bireylerin birbirleri ile olan etkileşimini hızlandırarak yerel toplumun ekonomik ve sosyal yönden hayat standardının artmasını sağladığı" şeklinde iki başlık altında gruplandırılmıştır. Araştırmada anket çalışması 389 kişi üzerinde yüz yüze görüşme yöntemiyle yapılmıştır. Araştırma sonuçları; Kastamonu halkının, turizmin sosyokültürel etkilerine ilişkin algılamalarının genel anlamda, kültürel, gelenek ve göreneklerin ağırlıklı olduğu durumlarda biraz daha çekimser, sosyal algılar içeren durumlarda ise daha kararlı oldukları şeklindedir. Bunların da ancak cinsiyet, yaş, eğitim, çalışma durumu, gelir düzeyi gibi demografik değişkenlere bağlı olarak değişiklik gösterdiği tespit edilmiştir.

Anahtar Kelimeler: Ekonomik Etki, Çevresel Etki, Sosyokültürel Etki, Kastamonu.

Makale Gönderme Tarihi: 08.10.2019

Makale Kabul Tarihi: 14.01 .2020

\section{Önerilen Atıf:}

Avcı, M. (2020). Turizmde Gelişmenin, Yöre Halkı Üzerinde Oluşturduğu Toplumsal ve Kültürel Etkilerin Araştırılması: Kastamonu Örneği, Türk Turizm Araştırmaları Dergisi, 4(1): 540-556.

(C) 2020 Türk Turizm Araştırmaları Dergisi. 


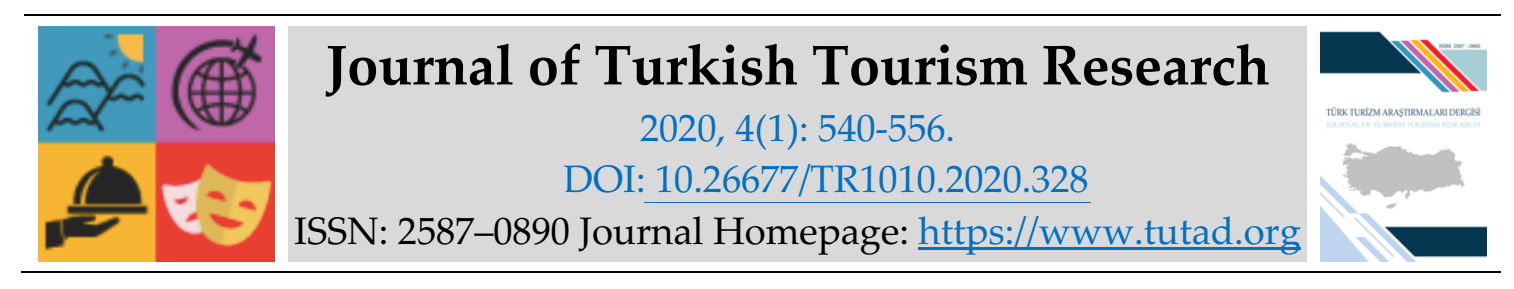

\title{
$\underline{\text { RESEARCH PAPER }}$
}

\section{Investigation of Social and Cultural Effects of Tourism Development on the Local People: The Case of Kastamonu}

Dr. Muharrem AVCI, Kastamonu University, Faculty of Tourism, Kastamonu, e-mail: mavci@kastamonu.edu.tr ORCID: https://orcid.org/0000-0002-0264-1181

\begin{abstract}
This research is a quantitative study aimed at determining how social and cultural influences are formed in the destination of Kastamonu which is a young region in tourism and to determine the perspectives of local people on this issue. In this study, a questionnaire, which was prepared according to the purpose and content, was used. The questionnaire consisted of two parts; 6 questions to determine the demographic variables of local people were included. In the second part, there are 13 questions prepared to measure the perspectives of local people in Kastamonu on sociocultural effects of tourism. In this research, the questionnaire was applied to 389 people by face-to-face interview method. Research results showed that the perception of the people of Kastamonu regarding the socio-cultural effects of tourism is generally more abstaining in cases where cultural, traditions and customs are predominant and more stable in situations involving social perceptions. It was also determined that these conditions changes depending on demographic variables such as gender, age, education, employment status and income level.
\end{abstract}

Keywords: Economic Impact, Environmental Impact, Sociocultural Impact, Kastamonu.

Received: 08.10.2019

Accepted: 14.01 .2020

\section{Suggested Citation:}

Avc1, M. (2020). Investigation of Social and Cultural Effects of Tourism Development on the Local People: The Case of Kastamonu, Journal of Turkish Tourism Research, 4(1): 540-556.

(C) 2020 Türk Turizm Araştırmaları Dergisi. 


\section{Gíriş}

Turizm; öznesi insan olan, olaylar ve ilişkiler bütünüdür. Son yıllarda oldukça hızlı bir şekilde gelişmiştir. Özellikle bu gelişmeler, II. Dünya savaşından sonra kendini göstermiş ve kitlesel bir özellik kazanarak devam etmiştir. Günümüzde endüstrileşmeyle birlikte birçok ülkede kişi başına düşen gelir artmış, gelişen teknoloji ile çalışma süreleri kısalmış, iletişim ve ulaşım ağları gelişmiş; boş zamanın artması, eğitim seviyesindeki yükselmeler, tatilin lüks değil bir ihtiyaç olarak görülmeye başlanması vb., ile turizmin; istihdamı artırması, döviz ve gelir sağlaması gibi doğrudan etkiler, turizmin güçlü bir ekonomik sektör haline gelmesini sağlamıştır (İlkin ve Dinçer, 1991: 38-39). Öte yandan, turizmin ekonomik etkisinin yanı sıra toplumsal bir olay olmasından kaynaklı sosyal ve kültürel olaylar üzerinde bir o kadar önemli etkilere sahip olduğu da fark edilmiştir.

Yapılan araştırmalar hem turizm faaliyetine katılan bireylerde hem de özellikle onlara gittikleri yerde her türlü hizmeti sunan yerli toplumun yapısında değişmeler olduğunu göstermiştir (Doğan, 2004: 37). Her yıl milyonlarca kişinin gerek ülke içi gerekse ülke dışı seyahatler yapmakta olduğu ve çok büyük bir nüfus hareketliliğine yol açtı̆̆ göz önüne alındığında, turizmde ekonomik etkiler kadar, sosyokültürel etkileşimlerin de dikkatle izlenmesinin gereği kaçınılmazdır. Bu kapsamda; bir bölgenin turizm gelişimini izlemek ve turizmin etkilerini sorgulamak büyük önem arz etmektedir.

Bir bölgede turizmin gelişmeye başlaması, bazı aşamalarla anlaşılır: İlk aşama (Başlama Dönemi), bölgenin keşfedilmesidir. Daha sonra (Gelişme Dönemi) bölgeye yapılacak olan bazı turizm yatırımlarının gelişidir. Devamında ise (Olgunluk Dönemi), çekicilik yüzdesi artış gösterir ve turist potansiyeli hızla artar. Yatırımlar bölgede bulunan ve yaşamlarını sürdürmekte olan halka da istihdam sağlar. Son aşamada ise (Düşüş Dönemi), bölgede ekonomik, çevresel, sosyal ve kültürel olumlu ve olumsuz değişiklikler görülmeye başlar (Olalı, 1990: 142).

Turizmin gelişim aşamasında, toplumun üzerinde ki etkisi üç kategoride açıklanmıştır: İlk olarak; artan vergi gelirleri, artan iş imkânları yani istihdam sağlama ve ek olarak elde edilen gelirler ve diğer yandan da bazı ekonomik çarpan etkileridir. İkinci olarak, geleneksel törenlerin, el sanatlarının yeniden canlılık göstermesiyle kültürel etkileşimin artması, diğer yandan suç işlenme oranlarında artış, geleneksel kültürel değişimler gibi sosyo-kültürel etkilerin görülmesidir. Üçüncü ise hava, su ve gürültü kirliliğinin oluşması ve çevresel sorunların boy göstermesidir (Özgüç, 1984: 103-104).

Turizmin bir bölgedeki gelişmişlik seviyesi, o bölgedeki yerel halk ile turistler arasındaki ilişkileri çok etkilemektedir. Örneğin; Turizmin fazlaca gelişmiş olduğu ve çok fazla sayıda turist çekme özelliğine sahip bölgelerde ekonomik, çevresel, sosyal ve kültürel bozulmalar gözlenebildiğinden, yerel halk bu duruma kayıtsız kalmayıp tepkiler gösterebilmekte ve bölgede bulunan turistlere kötü davranabilmektedirler. Turizmdeki gelişmeler; turist-yerel halk beklentilerini dikkate almalıdır (Doğan, 1987: 154-155).

Turizm gelişmesi için yapılacak çalışmaların; turistin beklentilerini ve isteklerini göz ardı etmeden, sürdürülebilir bir biçimde, turistleri sadece bir ekonomik kapı olarak görmeden gerçekleştirilmesi gerekmektedir (Doğal Hayatı Koruma Vakfı, 2000: 141-142).

En çok dikkat edilmesi gereken durumlar ise, çevresel ve bunun yanında sosyokültürel etkenlerdir. Turizm gelişimindeki ilerlemeler, yerel halkın yaşamını olumlu etkileyecek şekilde olduğu sürece, oluşması muhtemel olan turist yerel halk çatışmasının önüne geçilebilir. Yerel halkın turisti kabullenmesi ilk öncelik olmalıdır. Bu durum sağlandığında bölgede turizm gelişimi başarı ile sonuçlandırılabilir (Erdoğan, 1995: 191). 


\section{KAVRAMSAL ÇERÇEVE}

Turizmin etkilerini analiz etmek yani belirlemek oldukça zor ve zahmetli bir iştir. Çünkü turizm; gerek ekonomi gerekse çevre üzerinde derin izler oluşturan, toplumlardan etkilenme veya toplumları etkileme özelliğine sahip, gelenek ve görenekleri tesir altına alabilme kapasitesi taşıyan ve buna benzer birçok etkiyi bünyesinde barındıran ilişkiler ve olaylar bütünüdür. Bir başka ifadeyle; turizm, gelişme gösterdiği bir bölgede, olumlu ve olumsuz yönde, ekonomik, ekolojik, fiziksel ve sosyokültürel etkiler gösterebilmektedir (Seçilmiş, 2014: 212).

Turizmin Ekonomik Etkileri: Birçok ülke, bölge ve yerleşim alanlarında turizme verilen önemin başlıca nedeni ekonomik olarak getirilerinin fazla olmasıdır. Şüphesiz ki turizmin böyle bir yönü olduğu inkâr edilemez bir gerçektir.

Turist çeken bir ülke veya bölge ekonomik olarak yükselişe geçmektedir. Turistlerin gerçekleştirmiş oldukları ziyaretler sırasında yapmış oldukları harcamalar, milli gelirin artmasını sağlamaktadır. Turizm gelişimi yerel ekonomiyi rahatlatıp büyütmekte ve bu alanda yapılan çalışmaların artmasını sağlamaktadır.

Yapılan pek çok çalışmada turizmin gelişim süreci ve tanıtım faaliyetlerinde, sektörün insanları için yaratacağı yeni istihdam kaynağı, ülke ekonomisine sağlayacağı gelirler, yabancı farklılaşmalar ve toplumun alt yapısının gelişmesini sağladığı ve diğer endüstrileri de iştahlandırarak teşvik ettiği belirtilmiştir. Turizm, ekonomiye uyarıcı etkiler yapmasıyla birlikte ekonomik yapı değişimlerinin hızlanmasını sağlamıştır. Turizmin kırsal alanlara ekonomik etkileri ile birlikte bölgede olan iş alanlarında değişimler meydana gelmiş, farklı istihdam alanlarına eğilim artmıştır. Bunun turizm ile birlikte gelişimini başlatan bu bölgelerde arazi fiyatları artış göstermiştir (Sarı, 2014: 191).

Turizm hareketinin döviz arzını yükselterek dışarıya yapılacak olan ödemeler dengesine etki etmesi, gelir etkisi ve tekrar dağılımı yoluyla ekonomiyi canlandırması, içerideki fiyatlar üzerine etkisi, devletin gelirinin çoğalması rolü gibi etkileri moneter etkileri, İstihdam üzerinde olan etkisi, diğer farklı sektörlerin üzerinde oluşturduğu etkisi, alt yapıya olan etkisi vb. etkileri de reel (gerçek) ekonomik etkiler olarak değerlendirilmiştir (Avcıkurt, 2009: 35-36).

Turizm beklenenin aksine her zaman ekonomik katkı sağlamayabilir. Turizm ekonomik etkilerinin zararlı yönleri olarak; dışa bağımlılı̆̆ı artması, üretilen ürün ve hizmetlerin pahalılaşması ve enflasyon artışı, toplumda belirli ve az sayıda bir kesimin turizm üzerinde fayda sağlaması sonucu oluşabilecek olan adaletsizliklerin artması gibi konular gösterilebilir.

Turizmin Çevresel Etkisi: Turizm ve çevre birbirinden ayrılmaz bir bütün haline gelmiş, iç içe girmiş bir ilişki içerisindedir. Fiziksel çevre her alanda olduğu gibi turizmde de misafirlere çekicilik, cazibe sunmaktadır. Çünkü turizm olgusu fiziksel bir çevrede meydana gelmektedir. Turist hareketleri, fiziksel ve sosyal çevre olmak üzere iki gruptan oluşmaktadır. Turizm olayının meydana geldiği fiziki ortam coğrafi çevredir ve turizm etkinlikleri bu bölgelerde yapılmaktadır. Turizmin varlık sebebi doğal ve kültürel çevredir. Turizmin gelişimi ve devamlılığı çevreye endekslidir. (Mansuroğlu, 2006:36). Sosyal, ekonomik ve kültürel birçok faydası bulunan turizm sektörü, aşırı fazla doğal kaynak kullanımı ve hatalı mekân seçimleriyle doğal alanlara, tarihsel değerlere zarar verebilmektedir. Turizmin ana temelini oluşturan bu tür değerlerin uzun süreli korunabilmesi için turizm alanlarında yapılması planlanan aşamalarının tüm bölümünde yerel halkın dâhil edilmesi oldukça önem arz etmektedir (Güney, 1992:144).

Turizmin Sosyokültürel Etkileri: Turizm endüstrisinin ekonomik ve çevresel etkileri olduğu kadar göz ardı edilemeyecek ölçüde önemli olan sosyokültürel etkileri de vardır. Turizmin sağlamış olduğu ekonomik faydalar insanların yaşam kalitesini artırıyor olsa da, sosyokültürel faktörler göz önüne alındığında benzeri olumlu sonuçlar göstermeyebilir. 
Sosyal ve kültürel varlıklar; dünyayı denge, düzen ve uyum içine koyan değerler ve inançlardan meydana gelmektedir. Her etken, insanların kimliklerini tanımlayan ve nasıl davranış biçimleri edinmesini gösteren bilgi kaynağıdır. Değerler, inançlar ve sosyal ilişkiler arasındaki bağlar sosyal ve kültürel konseptlerin de iç içe girmesine sebep olmaktadır (Demircan, 2011: 120).

Turizmin, toplumlar ve toplum yapılarının üzerinde oluşturduğu etkilerin tam anlamıla idrak edilebilmesi için; bireylerin, sosyal ve kültürel yapılar üzerinde ki etkilerinin bilinmesi gerekir. Sosyal yapı denildiğinde bir toplumda örgütlenmiş olan ilişkilerin tümü akla gelir. Gelişmiş, az gelişmiş ya da gelişmekte olan ülkeleri, kırsal alanda yaşayan veya kentsel alanda yaşayan toplulukları, farklı farklı coğrafyadan insanları bütünleştirip birleştiren turizmin, sosyal yapıyı etkilemesi son derece olağandır (Kozak vd., 2001: 96).

Öte yandan bir toplumun üretmiş olduğu maddi ve manevi değerlerin tümü olarak bilinen kültürün de de değişimler olabilecektir. Kültür, turistik anlamda çekici olmanın en büyük parçalarından biridir. Turizmin kendisi için ise, turist ve yerel halk arasında bir uyum olması çok daha olumlu sonuçlar elde edilmesini sağlayacaktır (İncekara, 2001: 116).

Çok sayıda yapılmış olan araştırmada yerel toplumun memnuniyeti ile turizm gelişimin arasındaki ilişki incelenmiş, böylelikle turizme yönelik davranış ve turizm etkileri idrak edilmeye çalışılmıştır. Turizmin, destinasyon bölgelerinde meydana getirmiş olduğu sosyokültürel etkiler üzerine Türkiye' de yapılan literatür taramasından bazı örnekler şöyle sıralanabilir:

Mansuroğlu (2006) yapmış olduğu çalışmasında, turizm etkinliklerinin henüz yoğun olarak yapılmadığı, Antalya'nın Akseki İlçesi'nde yerli kesimin turizm gelişmelerine olan yaklaşımlarının ve fikirlerinin belirlemesini amaçlamıştır. Veri toplama tekniği olarak ölçümlü formlarla anket yöntemi kullanılarak değişik sosyoekonomik yapı içindeki insanlara anket çalışması uygulanmıştır. Ankete katılan Akseki halkının tamamına yakınının turizm olgusuna olumlu tepki verdiği tespit edilmiştir. Turizmin Akseki ve civarına faydalı olmayacağ savunanlar $(\% 2,2)$ ise, turizmin işlenen suç oranlarında artışa neden olacağı ve var olan doğal yapıyı zedeleyeceğini düşündükleri ifade edilerek vurgulanmıştır.

Uslu ve Kiper (2006) yapmış oldukları çalışmalarında, yerel halkın (Beypazarı) turizm hakkındaki görüsslerini belirlemeyi amaçlamışlardır, araştırma sonucunda bölge halkının \%91'i, turizmin pozitif yönde olan etkilerini hissettiklerini belirtmişlerdir. Bu pozitif etkiler yüksek oranda, el sanatlarının yeniden canlanması ve meşhur yöresel yemeklerin özünün korunup devam etmesinde görülmüştür. Bölge halkının \%10'luk kısmı ise, turizmin negatif durumlar oluşturduğunu bildirmiş; turizm olayının karşısında olup negatif yaklaşımlar içerisinde olanlar, turizmin adet, gelenek ve görenek gibi değerleri yozlaştırdığı görüşünü savunmuşlardır.

Alaeddinoğlu (2008) Sivas şehrinde yaşamlarını sürdüren yerli kesimin turiste ve turizme bakış açısını incelemiştir. Araştırmanın sonucunda, yerel halkın, şehre gelen turiste ve de turizm olayına olumlu şekilde baktığı ve geliştirilecek yeni turizm fikirlerini destekledikleri bulgularına ulaştıklarını belirtmiştir. Bunun yanı sıra turizmin birçok sayıda nesneye bir talep oluşturarak, toplum içerisindeki insanların ahlaklarını bozacağına, giyim ve kuşam konusunda alışkanlıklarını farklılaştıracağına ve halkın tüketim konusunda sahip oldukları alışkanlıkları üzerinde de etkili olacağına inandıklarını tespit etmiştir.

Gümüş ve Özüpekçe (2009) ise çalışmalarında, Foça ilçesinde yaşayan halkın turizmin etkilerinden olan (ekonomik, sosyal, kültürel ve çevresel) yönelik fikirlerini belirlemek; fikirlerin kırsal ya da kentsel, cinsiyet, öğrenim durumuna ve mesleğine göre farklılıklarını incelemişlerdir. Ulaşılan sonuçlar ışığında, Foça'da turizm etkinliklerine yönelik fikirlerin genel olarak pozitif yönde olduğu, kırsal ve kentsel yerleşimlerde yaşamaya, mesleğe, cinsiyete göre anlamlı değişiklikler içermediği tespit edilmiştir. Özellikle Foça' da yerli halkın turizm sayesinde bölgeye 
yapılan göçlerin artış gösterdiği, kadınların çalışma hayatındaki varlıklarına katkıda bulunduğu ve özellikle genç kesimin etkilenme sonucu anadillerinin bozduğunu düşündüklerini belirtmektedir.

Antalya Akseki, Ankara Beypazarı, Sivas ve İzmir Foça ilçesinde gerçekleştirilen alan araştırmaları sonuçlarına göre, destinasyon gelişiminde; sosyokültürel ve sosyoekonomik alanlarda, turizmin etkilerinin yerel halk üzerinde olumlu ve olumsuz boyutlarda olabildiği gözlemlenmiştir. Durumun, periyodik bir biçimde gelişmekte olan yörelerde de izlenmesi gerektiği düşüncesinden hareketle, konuyla ilgili olarak, turizmde genç bir yöre olan Kastamonu'da gelişme sürecinde, böyle bir çalışmaya ihtiyaç duyulmuştur. Bu çalışma, turizm olayının son yıllarda gelişmeye başlandığı ve birçok yönden etkilerinin hissedildiği bölgelerden biri durumuna gelen Kastamonu için gerçekleştirilmiştir.

\section{Kastamonu'nun Turistik Ürün Yapısında, Sosyokültürel Dokunun Yeri ve Önemi}

Turizm pazarlama karması elemanlarının temelini meydana getiren turistik ürün; turistin seyahati boyunca haz duyduğu doğal ve kültürel kaynaklar, yararlandığı ulaştırma, konaklama, yeme - içme ve diğer pek çok ürün ya da hizmetin birleşimden oluşmaktadır (Gürbüz, 2002:51).

Kastamonu'nun turistik ürün yapısı içerisinde sosyokültürel dokusu incelendiğinde, merkez ilçenin öncelikli olarak tarihi ve kültürel yapısı ön plana çıkmaktadır. Bu donanım, kadim şehri 2018 Türk Dünyası Kültür Başkenti yapmıştır (Türksoy, 2018). Kastamonu geneli; anıtları ve müzeleri, konakları, külliyeleri ve camileri, kış turizmi için uygun alanları, deniz turizmine yatkın bölgeleri ve daha birçok doğal ve tarihi yapıtları ile kendine hayran bırakan bir il olma özelliğini taşımaktadır (Kuzey Anadolu Kalkınama Ajansı, 2018: 122-126).

İnanç turizmi anlamında Kastamonu çok köklü bir geçmişe sahiptir. Bünyesinde bulundurduğu tarihsel yapıların çoğu, Türk-İslam kültürünü yansıtan yapılardır. Bu yapılar günümüzde de kullanılmaya devam etmektedir. İnşa edilişleri, 650 yıl öncesine dayanan bu yapılar (Kasaba köyü Mahmutbey Camii-1366, diğer adıyla Çivisiz camii- Unesco Kültür Miras Listesi adayı) Kastamonu insanının geçmişle olan bağını her zaman diri tutmaktadır.

Kastamonu bugün ki haliyle, Selçuklu, Candaroğulları ve de Osmanlı zamanlarından kalan çok sayıda yapıt (cami, medrese, han, hama vb.), ile din büyüklerinin bu yörede yaşamış olmaları ve türbelerinin bu topraklarda bulunmasından dolayı, kültür ve inanç turizmine ilgi duyan kesimin dikkatini çekmektedir. Burada bahsedilmesi gereken en önemli yapılardan biri de Hz. Pir Şeyh Şaban-1 Veli Türbesi ve Külliyesidir. Kastamonu' da en çok ziyaretçi çeken yerlerden biri olmakla birlikte çeşitli haftalık sohbetleri ve etkinlikleri ile yerli halka da hitap etmektedir (Avcı, 2019: 5256).

Sahabe-i Kiramdan olduğu bilinen Kays-ül Hemedanî Asgar Hazretleri'nin bulunduğu Hepkebirler Camii ve Türbesi, Aşıklı Sultan, Hatun Sultan, Müfessir Alaattin, Karanlık Evliya, Abdülfettah-ı Veli türbeleri ilk olarak ziyaret edilen mekânların arasında yer almaktadır. Şehir merkezi ve İ'in bütününe yayılmış külliyeler, mimari sanat eseri olan cami ve türbeler Kastamonu'ya, kutsal bir atmosferin sahipliğini üstlendirir (Kastamonu Belediyesi, 2018).

Her yılın Mayıs ayı birinci haftasında "Şeyh Şaban-ı Veli ve Kastamonu Evliyaları Anma Haftası" etkinlikleri düzenlenmekte ve faaliyetlere yerli halkın yanı sıra, komşu ve diğer şehirlerden gelen ziyaretçiler büyük ilgi göstermektedirler. "Evliyalar Şehri” olarak nam salmış olan Kastamonu'da birçok âlimden geriye insanlığa miras kalan eserler ve hatıralar büyük ilgi görmektedir (Kuzey Anadolu Kalkınama Ajansı, 2018). 
Kastamonu'da inanç turizmi adı altında düzenlemiş özel gün ve programlar bulunmaktadır. Bunlar;

-Uluslararası Hz. Pir Şeyh Şaban-ı Veli ve Kastamonu Evliyaları Anma Haftası: Her senenin birinci Mayıs haftası,

-Mehmet Feyzi Efendi'yi Anma Günü: Her yılın 9 Mart'tır.

Yapımı Osmanlı Padişahlarından II. Beyazıt dönemine ait, 1506 yılında Nasrullah Kadı tarafından gerçekleştirilmiş olan cami, Kastamonu'nun en merkezi camisi olma özelliğine sahiptir. Milli mücadele döneminde İstiklal Marşımızın yazarı Mehmet Akif Ersoy, Nasrullah Camii'nde halka hitap etmiş ve Kurtuluş Savaşı için onları, yüreklendirmiştir. Cepheye kağnılarla mühimmat ve erzak taşınan İstiklal Yolu'nun (Günümüzde ki İnebolu-KastamonuÇankırı ve Ankara kültür rotası) cesaretinin yüklendiği yer, bu mekândır. Hemen aynı bölgede bulunan ve adını Camii'nden alan, şadırvan, köprü, meydan ve çevresi, tarihi özellikleriyle birçok kişinin gelip görmeden geçmediği, camii içerisini ziyaret etmeden, şadırvanından su içmeden, köprüsünde fotoğraf çektirmeden gitmediği alanlardan biridir.

Kastamonu ilinde sayıları bir hayli fazla olan sivil mimari somut kültürel mirasların başında konaklar gelmektedir. Yalnızca şehir merkezinde 350 adet konak bulunmakta ve bu konaklar, 100 yıldan daha uzun süredir yıkılmadan ayakta durmaktadır (Kastamonu Valiliği, 2018:141). Merkez bölgesinin ardından Taşköprü ve İnebolu ilçelerinde de konak sayısı fazladır. Kastamonu Konakları olarak adlandırılan bu tarihi eserler, restorasyonları sonrası turizmde işlev kazandırılmasıyla bu yörenin kültür turizminde önemli etken olma yolundadır.

Kastamonu bütün tarih dokusu ve manevi değerlerinin yanı sıra tabiat turizm için de son derece büyük bir potansiyele sahiptir. Küre Dağları Milli Parkı sürdürülebilir turizm alanında göstermiş olduğu faaliyetler ve gösterilen iyi yönetim sayesinde 2012 yılında PAN Park Sertifikası almıştır. Bu sonuç ile Türkiye'de bunu başaran ilk Panpark olmuştur. Avrupa bazında ise 13. Panpark ünvanını almıştır. Bunların yanında Kastamonu; dünyanın en derin 2. Kanyonu olan Valla Kanyonu, dünyanın en büyük 4. Mağarası olan Ilgarini Mağarası, Cam seyir terasları; Çatak ve İncekaya Kanyonları, 10 metrelik Ilıca Şelalesi ve yürüyüş parkurlarıyla Horma kanyonuna sahip bir doğa harikasıdır (Kuzey Anadolu Kalkınama Ajansı, 2018: 70-82).

Kış turizmi anlamında bilinen en güzel bölge Ilgaz Dağı Milli Parkı'dır. Kış turizminin merkezi olma özelliğini taşır. İl merkezine olan uzaklığg 40 km'dir. Ilgaz Dağı içerisinde yer alan milli park içerisinde toplamda 7, dışında ise 1 adet kamu ve özel sektöre hizmet veren tesis bulunmaktadır. Kayak pisti olarak kullanılan 2 adet aktif kayak merkezi bulunmaktadır. Bunlar $800 \mathrm{mt}$ ve 1500 mt uzunluğundadır. Teleferikler vasıtasıyla kayak merkezlerinde ulaşım sağlanmaktadır (Öncü vd., 2018).

Kastamonu İl'inde ki bir diğer turizm potansiyeli ise Deniz Turizm'dir. Kastamonu 170 km'lik sahil şeridi ile bu alanda Karadeniz'e sınırı bulunan iller arasında en geniş sahil alanına sahip şehirdir. Sahil şeridi içerisinde bulunan ilçeleri; Cide, Doğanyurt, İnebolu, Abana, Bozkurt ve Çatalzeytin'dir. Bu ilçelerin en önemli avantajları içinde barındırmış oldukları doğal koy ve barınaklarla farklılık yaratmasıdır. Sahil boyunca uzanan dalış alanları, doğal plajlar ve limanlar bulunmaktadır. Yeşil ve mavinin buluştuğu Kastamonu sahil şeridi, çok doğal bir yapıya sahiptir. 


\section{YÖNTEM}

\section{Araştırmanın Problemi}

Turizmin ivme kazandığı 1990'li yılların ilk zamanlarından günümüze kadar geçen süre içinde turizmin sosyokültürel etkileriyle ilgili birçok araştırma yapılmış ve her zaman üzerinde durulan bir konu olmuştur. Böyle olmak zorundadır zira turistik bölgede yaşamını sürdürmekte olan halkla iletişim kurulmadığı takdirde, oluşabilecek değişimlerin gerçek anlamını belirlemek mümkün değildir. İşte, bu problem, çalışmanın temelini oluşturmuştur. Bu çalışmada, araştırmanın gerçekleştirildiği yöre, Kastamonu'dur. Bu il, turizmle yeni tanışmış olup yeterli araştırma da henüz mevcut değildir. Tüm bu sorunlar, böyle bir araştırmanın ele alınması gereğini ortaya koymuştur.

Yürütülen bu araştırmayla öncelikli olarak; "Yerel halkın hayat tarzı ile turizmin sosyokültürel etkileri arasında anlamlı bir ilişki var mıdır?" sorusuna cevap aranmıştır.

Bu kapsamda araştırma değişkenleri; a) "turizmin ahlaki ve kültürel değerleri tahrip ederek toplumsal hayatı olumsuz yönde etkilediği", b) "turizm, farklı toplumları temsil eden bireylerin birbirleri ile olan etkileşimini hızlandırarak yerel toplumun ekonomik ve sosyal yönden hayat standardının artmasını sağladığı" şeklinde iki başlık altında gruplandırılmıştır.

\section{Araştırmanın Amacı}

Bu çalışmanın amacl; güçlü doğal, kültürel ve sosyal turistik donanıma sahip olan Kastamonu yöresi ile burada yaşayan halkın hayat tarzını belirlemek ve daha işin başında turizminin sosyokültürel etkilerinin hayat tarzları üzerinde belirgin bir değişime neden olup olmadığını analiz etmektir. Bu amaç doğrultusunda araştırmaya ilişkin olarak geliştirilen hipotezler şu şekildedir:

Temel hipotez; Katılımcıların demografik özellikleri ile araştırma faktörlerine yönelik algılama ve değerlendirmeleri arasında anlamlı bir ilişki vardır.

H1: Kadın ve erkek katılımcıların araştırma faktörlerine yönelik algılama ve değerlendirmeleri arasında anlamlı bir farklılık vardır.

H2: Katılımcıların yaşlarının ve araştırma faktörlerine yönelik algılama ve değerlendirmeleri arasında anlamlı bir farklılık vardır.

H3: Katılımcıların eğitim durumları ve araştırma faktörlerinden birinci faktöre (olumsuz etkiler) yönelik algılama ve değerlendirmeleri arasında anlamlı bir farklılık vardır.

H4: Katılımcıların eğitim durumları ve araştırma faktörlerinden ikinci faktöre (olumlu etkiler) yönelik algılama ve değerlendirmeleri arasında anlamlı bir farklılık vardır.

H5: Katılımcıların çalışma durumları ve araştırma değişkenlerine yönelik algılama ve değerlendirmeleri arasında anlamlı bir farklılık vardır.

H6: Katılımcıların aylık gelir düzeyi ve araştırma değişkenlerine yönelik algılama ve değerlendirmeleri arasında anlamlı bir farklılık vardır.

\section{Araștırmanın Önemi}

Yerel halkın turizm konusundaki algılarını öğrenmeye yönelik araştırmalar planlamacılara önemli katkılar sunabilmektedir. Örneğin yerel halkın niçin sektöre destek verdiği veya karşı 
çıktığı konusunda bilgi sahibi olunması durumunda; turizmin olumsuz sosyokültürel etkilerinin azaltılabilmesi veya bu etkilere karşı desteğin artırılabilmesine imkân tanınarak yerel halkın hayat kalitesi artırılabilecek veya en azından korunabilecektir. Araştırmanın ana hareket noktası, yerel halkın yaşam tarzlarının zaman içerisinde sosyokültürel yeniliklerle değişime uğrayıp, farklı sosyal ve kültürel alışkanlıklar edinilmesinde turizmin sosyokültürel yeniliklerinin önemli bir role sahip olması yatmaktadır. Yürütülen bu çalışma, hem akademik alandaki hayat tarzı araştırmalarına bir katkıda bulunmayı, hem de Kastamonu'da turizmin sosyokültürel yeniliklerinin hayat tarzları üzerine etkilerinin birlikte ele alındığı bilimsel bir araştırma olması ve böyle bir çalışmanın yörede bulunmaması nedeniyle alandaki boşluğu doldurmayı hedeflemektedir.

\section{Araştırmanın Yöntemi}

Bu araştırmada yöntem olarak nicel araştırma modellerinde tarama modeli işe koşulmuştur. Veri toplama aracı olarak yazar tarafından anket formu geliştirilmiştir. Araştırmada veriler, Kastamonu'da ikamet eden ve gönüllü olarak ankete cevap verenlerden elde edilmiştir. Anket çalışması 389 kişi üzerinde yüz yüze görüşme yöntemiyle yapılmıştır.

Anket formu iki bölümden ibarettir: Birinci bölümde katılımclara ilişkin demografik sorular, ikinci bölümde ise Kastamonu halkının turizmin sosyokültürel etkilere bakış açılarını ölçmeye yönelik olarak hazırlanmış 13 adet soru yer almıştır. Konuyla ilgili 5 faktörel başlık bulunmaktadır. Ölçekte 5'li Likert tipi (1. Kesinlikle katılmıyorum, 2. Katılmıyorum, 3. Kararsızım, 4. Katılıyorum, 5. Kesinlikle katılıyorum) derecelendirme sistemi kullanılmıştır.

\section{Evren ve Örneklem}

$\mathrm{Bu}$ çalışmanın ana kütlesini, Kastamonu ilinde ikamet eden yerel halk oluşturmaktadır. Araştırma, Kastamonu ili merkezinde gerçekleştirilmiştir. Ankete katılan kişiler, basit tesadüfî örnekleme yöntemine göre Kastamonu ili merkezinin nüfusu temel alınarak belirlenmiştir. Örnekleme alınan kişiler konuyla ilgili eğitilmiş anketörler tarafından bireylerin kendi rızası alınarak seçilmiştir.

\section{Veri Toplama ve Analiz}

Araştırmada ilk olarak, anahtar sözcüklerin açıklamaları ve ilgili konuda yapılmış çalışmaların neler olduğu tespit edilmiş olup bir anketle birincil veriler toplanmıştır. İkinci aşamada, formlardaki cevaplar kodlanarak "SPSS (Statistical Package For Social Sciences-Sosyal Bilimler İçin İstatistik Paketi) ile analiz edilmiştir (Sayım, 2017:247). Anket içerisinde yer alan 13 önermeye uygulanan güvenilirlik testi sonucunda güvenilirlik katsayısı Cronbach Alpha $\alpha=0.926$ olarak belirlenmiş̧ir. Bulunmuş olan değer kat sayısı güvenilirlik ölçütü kabul görülen 0.50 ila 0.90 arasında bir değer olmasından dolayı ankette yer alan ifadelerin güvenilirlik oranların istatiksel bazda yeterli bir seviyede olduğundan yola çıkılarak, tutarlı ve güvenilir bir ölçek olduğu söylenebilir. 


\section{BULGULAR VE YORUM}

Tablo 1'de faktör analizi sonucun da elde edilen 2 faktör ve bunlara ilişkin varyansı açıklama oranı, toplam varyansı ve her bir faktör içeriğine uygulanan güvenilirlik testi Cronbach Alfa ile ölçekte yer alan her bir maddenin hangi faktörle ilişkili olduğunu belirten faktör yük değerleri gösterilmiştir. Buradan yola çıkılarak; “Turizm ahlaki değerleri tahrip ederek toplumsal yaşamı olumsuz yönde etkiler", Tablo 1'de ki faktör analizinin sonuçlarına bakıldığında, faktör 1'de yer alan araştırma önermelerinin açıklanan varyans oranı $(\% 42,998)$ değerindedir. Toplam varyansa bakıldığında onun da $(42,998)$ olarak bulunduğu görülmektedir. Turizm ahlakı değerleri tahrip ederek toplumsal hayatı olumsuz yönde etkiler sonucunda güvenilirlik kat sayısı Cronbach Alpha $\alpha=, 926$ olarak belirlenmiştir.

Tablo 1. Faktör Analizi

\begin{tabular}{|c|c|c|c|c|}
\hline Faktörler & $\begin{array}{l}\text { Faktör } \\
\text { Yükleri } \\
\end{array}$ & $\begin{array}{c}\text { Açılanan } \\
\text { Varyans (\%) } \\
\end{array}$ & $\begin{array}{c}\text { Toplam } \\
\text { Varyans } \\
\end{array}$ & $\begin{array}{c}\text { Cronbach } \\
\text { Alfa }\end{array}$ \\
\hline $\begin{array}{l}\text { Faktör 1: Turizmin ahlaki değerler üzerine } \\
\text { olumsuz etkisi }\end{array}$ & & 42.998 & 42.998 & ,926 \\
\hline $\begin{array}{l}\text { Turizm, yöre halkının yaşayış tarzını olumsuz } \\
\text { etkiler. }\end{array}$ & 828 & & & \\
\hline Turizm, toplum ahlakını tehdit etmektedir. & 823 & & & \\
\hline $\begin{array}{l}\text { Turizmin gelişmesi, gelenek ve görenekleri } \\
\text { kaybettirir. }\end{array}$ & 810 & & & \\
\hline $\begin{array}{l}\text { Turizmin getirdiği para, insanlar arasındaki } \\
\text { güven ortamını tahrip etmektedir. }\end{array}$ & ,790 & & & \\
\hline $\begin{array}{l}\text { Kastamonu'nun gelenek, örf ve adetleri } \\
\text { turizmden negatif yönde etkilenmektedir. }\end{array}$ & ,780 & & & \\
\hline $\begin{array}{l}\text { Turizm, özellikle gençlerin değer ve inanç yapısı } \\
\text { üzerinde olumsuz etki bırakarak, giyim ve } \\
\text { yaşam biçimlerinde değişimler meydana } \\
\text { getirmiştir. }\end{array}$ & ,771 & & & \\
\hline $\begin{array}{l}\text { Turizm, manevi değer ve inançlarımızı } \\
\text { kaybetmemize yol açmaktadır. }\end{array}$ & ,770 & & & \\
\hline $\begin{array}{l}\text { Turizmle birlikte alkol ve uyuşturucu benzeri } \\
\text { zararlı alışkanlıklar, artış göstermiştir. }\end{array}$ & ,734 & & & \\
\hline $\begin{array}{l}\text { Turizmin gelişimi ile birlikte insani ilişkiler, } \\
\text { yerini ekonomik çıkarlara bırakmıştır. }\end{array}$ & ,717 & & & \\
\hline $\begin{array}{l}\text { Faktör 2: Turizmin yerel topluma ekonomik } \\
\text { ve sosyal yönden olumlu etkileri }\end{array}$ & & 20,706 & 63,703 & 849 \\
\hline $\begin{array}{l}\text { Turizmle başka toplumlara saygı duyma } \\
\text { öğrenilmektedir. }\end{array}$ & ,788 & & & \\
\hline $\begin{array}{l}\text { Turizm, yerel halka bir iş, ilgi ve faaliyet alanı } \\
\text { oluşturmaktadır }\end{array}$ & ,756 & & & \\
\hline $\begin{array}{l}\text { Turizmin etkisi ile Kastamonu'da, kimi sanat ve } \\
\text { meslekler, el sanatları ve yerel kültürün diğer } \\
\text { unsurları canlanmakta ve değer kazanmaktadır }\end{array}$ & ,747 & & & \\
\hline $\begin{array}{l}\text { Turizm sayesinde farklı kültürler hakkında yeni } \\
\text { şeyler öğrenmek mümkün olup bu durum yöre } \\
\text { insanını mutlu etmektedir. }\end{array}$ & 660 & & & \\
\hline $\begin{array}{l}\text { Kaiser-Meyer-Olkin Measure of Sampling } \\
\text { Adequacy (KMO) }\end{array}$ & \multicolumn{4}{|c|}{,866 } \\
\hline Bartlett's Test of Sphericity & \multicolumn{4}{|c|}{ 3562,907; Sig: ,000 } \\
\hline Toplam varyansı açıklama oranı \% & \multicolumn{4}{|c|}{$\% 63,70$} \\
\hline Cronbach Alpha & \multicolumn{4}{|c|}{,926 } \\
\hline
\end{tabular}

"Turizmin yerel halkın yaşam biçimi üzerine katkıda bulunarak olumlu etkiler yaratmıştır", faktör analizi sonucunda bu başlık altında toplanan değişkenlerin açıklanan varyans oranı (\%20.706) değerinde olduğu tespit edilmiştir. Toplam varyans ise (63.703) olarak görülmektedir. Turizmin yerel halk üzerinde olumlu etkiler yarattığına ilişkin faktörünün ele aldığı 
değişkenlerin yapılan güvenilirlik testi sonucunda güvenilirlik oranı Cronbach Alpha $\alpha=0.849$ olarak tespit edilmiştir. Yapılan faktör analizi sonunda ulaşılan değişkenlerin ortak varyans (communality) değeri $(69,84)$ olarak alınmıştır. Ölçeğin KMO (Kaiser-Meyer-Olkin Measure of Sampling Adequacy) değeri ise, 866 seviyelerinde tatminkâr bir değere ulaşılmıştır. KMO, örneklem yeterlilik ve uygunluğunun ölçüsü olarak kabul görülür ve 0,6 'dan daha büyük bir değer olması arzu edilir. Bundan dolayı elde edilen istatistik grubunun faktör analizi için fazlasıyla tatmin edici ve iyi seviyede olduğu söylenebilir. Yapılan araştırmalar sonucu elde edilen verilerinden anlamlı faktörler veya değişkenler çıkarılabileceğini gösteren küresellik derecesi de (Bartlett's Test of Sphericity) 3562,907 sig=0,00 şeklinde bulunuş ve bulunan bu değerin istatistiksel bazda anlamlı olduğu tespit edilmiştir. Yapılan bu iki test sonucu elde edilen bulgular, faktör analizi yapabilmek için üzerinde çalışma yürütülen örneklem büyüklügünün yeterli, verilerin de faktör analizi için uygun olduğunu göstermektedir.

Tablo 2. Demografik Veriler

\begin{tabular}{|c|c|c|c|c|}
\hline & $\mathbf{n}$ & $\%$ & Geçerli \% & Birikimli \% \\
\hline \multicolumn{5}{|l|}{ Cinsiyet } \\
\hline Erkek & 217 & 55.5 & 55.5 & 99.7 \\
\hline Kadın & 172 & 44.2 & 44.2 & 44.2 \\
\hline Total & 389 & 100,0 & 100,0 & \\
\hline \multicolumn{5}{|l|}{ Yaş } \\
\hline 15-24 yaş & 59 & 15.2 & 15.2 & 15.2 \\
\hline 25-34 yaş & 140 & 36.0 & 36.0 & 51.2 \\
\hline 35-44 yaş & 114 & 37.0 & 37.0 & 88.2 \\
\hline 45 ve üzeri yaş & 46 & 11.8 & 11.8 & 100.0 \\
\hline Toplam & 389 & 100,0 & 100,0 & \\
\hline \multicolumn{5}{|l|}{ Eğitim Durumu } \\
\hline İlkokul & 50 & 12.9 & 12.9 & 12.9 \\
\hline Lise & 124 & 31.9 & 31.9 & 44.7 \\
\hline Ön lisans & 51 & 13.1 & 13.1 & 57.8 \\
\hline Lisans & 143 & 36.8 & 36.8 & 94.6 \\
\hline Doktora & 14 & 3.6 & 3.6 & 100,0 \\
\hline Toplam & 389 & 100,0 & 100,0 & \\
\hline \multicolumn{5}{|l|}{ İş Durumu } \\
\hline $\begin{array}{l}\text { Öğrenci } \\
\text { (Yüksek Öğrenim) }\end{array}$ & 51 & 13.1 & 13.1 & 13.1 \\
\hline Çalışıyor & 297 & 76.3 & 76.3 & 89.5 \\
\hline Çalışmiyor & 20 & 5.1 & 5.1 & 94.6 \\
\hline Öğrenci (lise) & 21 & 5.4 & 5.4 & 100.0 \\
\hline Toplam & 389 & 100,0 & 100,0 & \\
\hline \multicolumn{5}{|l|}{ Çalışma Alanı } \\
\hline Kamu & 95 & 24.4 & 24.4 & 24.4 \\
\hline Özel & 201 & 51.7 & 51.7 & 76.1 \\
\hline Boş & 389 & 100.0 & 100.0 & \\
\hline \multicolumn{5}{|l|}{ Aylık Gelir Düzeyi } \\
\hline 550 TL'den az & 6 & 1.5 & 1.5 & 1.5 \\
\hline 551-1000 TL aras1 & 32 & 8.2 & 8.2 & 9.8 \\
\hline 1001-1500 TL aras1 & 29 & 7.5 & 7.5 & 17.2 \\
\hline 1501-2000 TL arası & 114 & 29.3 & 29.3 & 46.5 \\
\hline 2001-3000 TL arası & 119 & 30.6 & 30.6 & 77.1 \\
\hline 3001-4000 TL aras1 & 58 & 14.9 & 14.9 & 92.0 \\
\hline 4001 TL ve üzeri & 31 & 8.0 & 8.0 & 100.0 \\
\hline Toplam & 389 & 100.0 & 100.0 & Toplam \\
\hline
\end{tabular}


Tablo 3. Kastamonu Halkının Turizme Karşı Olan Tutumu

\begin{tabular}{|l|c|c|}
\hline Faktör ve Faktör Önermeleri & Ortalaması & Standart Sapması \\
\hline $\begin{array}{l}\text { Faktör 1: Turizm ahlakı değerleri tahrip ederek } \\
\text { toplumsal yaşamı olumsuz yönde etkiler. }\end{array}$ & & 1,16 \\
\hline Turizm yöre halkının yaşam biçimlerini olumsuz etkiler & 3,51 & 1,37 \\
\hline $\begin{array}{l}\text { Kastamonu'nun gelenek, örf ve adetleri turizmden } \\
\text { negatif yönde etkilenmektedir. }\end{array}$ & 3,40 &, 989 \\
\hline Turizmin gelişmesi, gelenek ve görenekleri kaybettirir. & 3,34 & 1,00 \\
\hline Turizm toplum ahlakını tehdit etmektedir. & 3,31 & 1,30 \\
\hline $\begin{array}{l}\text { Turizm ile birlikte alkol ve uyuşturucu benzeri zararlı } \\
\text { alışanlılar artış göstermektedir. }\end{array}$ & 3,29 & 1,09 \\
\hline $\begin{array}{l}\text { Turizmin gelişimi ile birlikte insani ilişkiler, yerini } \\
\text { ekonomik çıarlara bırakmaktadır. }\end{array}$ & 3,25 \\
\hline $\begin{array}{l}\text { Turizmin getirdiği para, insanlar arasındaki güven } \\
\text { ortamını tahrip etmektedir }\end{array}$ & 3,24 &, 990 \\
\hline $\begin{array}{l}\text { Turizm, manevi değer ve inançlarımızı kaybetmemize } \\
\text { yol açmaktadır. }\end{array}$ & 3,21 & 1,03 \\
\hline $\begin{array}{l}\text { Özellikle gençlerin değer ve inanç yapısı üzerinde } \\
\text { olumsuz etki bırakarak, giyim ve yaşam biçimlerinde } \\
\text { değişimler meydana gelmiştir }\end{array}$ & 3,19 & 1,06 \\
\hline $\begin{array}{l}\text { Faktör 2: Turizm farklı toplumları temsil eden } \\
\text { bireylerin birbirleri ile olan etkileşimini } \\
\text { hızlandırarak yerel toplumun ekonomik ve sosyal } \\
\text { yönden yaşam standardının artmasını sağlar }\end{array}$ & 2,01 \\
\hline Turizm, başka toplumlara saygı duymayı sağlar & 2,53 & \\
\hline $\begin{array}{l}\text { Turizmin etkisi ile Kastamonu'da kimi sanatlar, el } \\
\text { sanatları ve yerel kültürün diğer unsurları canlanmakta } \\
\text { ve değer kazanmaktadır }\end{array}$ & 2,55 & 1,18 \\
\hline $\begin{array}{l}\text { Turizm sayesinde farklı kültürler hakkında yeni şeyler } \\
\text { öğrenmek insanı mutlu etmektedir. }\end{array}$ & & \\
\hline $\begin{array}{l}\text { Turizm, yerel halka bir iş, ilgi ve faaliyet alanı } \\
\text { oluşturmaktadır }\end{array}$ & & \\
\hline & & \\
\hline
\end{tabular}

Tablo 3'de yer alan Kastamonu ilin de yaşayan yöre halkının turizmin sosyal ve kültürel etkilerine yönelik tutumlarının ayrıntılı olarak belirlenmesi amacıyla her bir faktörde yer alan önermelerin dağılımları ele alınmıştır. Bu bağlam sonucunda yöre halkının her bir önermeye verdiği cevapların ortalaması alınmıştır.

“Turizm yöre halkının yaşam biçimlerini olumsuz etkiler." Tablo 3'e bakıldığında Kastamonu halkının genel olarak turizm ahlaki değerleri ve toplumsal yaşamı olumsuz etkilediği başlığ altında bulunan değişkenler konusunda kararsız oldukları görülmektedir. Bu başlık altındaki değişkenler irdelendiğinde;

Turizm yöre halkının yaşam biçimlerini olumsuz etkiler değişkeni konusunda kararsız $(x=3,51)$ olduğu görülmektedir. Toplum ahlakı $(x=3,31)$, gelenek ve göreneklerin kaybedilmesi $(x=3,97)$, turizmden elde edilen gelirin bireyler arasındaki güven ortamın tahrip ettiği $(x=3,24)$, örf ve adetlerin negatif yönde etkilendiği $(x=3,40)$, gençlerin inanç ve yaşam şekilleri üzerinde olumsuz etkiler bırakması $(x=3,19)$, toplumun benimsemiş olduğu manevi değer ve inançların kaybedilmesi $(x=3,21)$, alkol, uyuşturucu ve zararlı alışkanlıkların artış göstermesi $(x=3,29)$, turizmin gelişimi ile insani değerlerin kaybedilip ekonomik çıarların arttığı $(x=3,25)$ görülmektedir. Tüm bunlara bakıldığında ahlakı değerleri tahrip ederek toplumsal yaşamı olumsuz etkilediği başlığı altındaki diğer tüm değişkenler de kararsız bir tutum içerisinde oldukları gözlenmektedir. 
Tablo 4. T-Testi ve Varyans (Anova) Analizi Sonuçları

\begin{tabular}{|c|c|c|c|}
\hline $\begin{array}{ll}\text { Katılımciların } & \text { Tanitıcı } \\
\text { Özellikleri } & \\
\end{array}$ & & $\begin{array}{c}\text { Faktör } 1 \\
\text { Olumsuz etki } \\
\end{array}$ & $\begin{array}{c}\text { Faktör } 2 \\
\text { Olumlu etki }\end{array}$ \\
\hline Cinsiyet & $\mathbf{n}$ & $x \pm s s$ & $x \pm s s$ \\
\hline Erkek & 217 & $\begin{array}{l}3,38 \pm \\
, 846\end{array}$ & $\begin{array}{l}2,72 \pm \\
, 726\end{array}$ \\
\hline Kadın & 172 & $\begin{array}{l}3,21 \pm \\
, 938\end{array}$ & $\begin{array}{c}2,75 \pm \\
, 651 \\
\end{array}$ \\
\hline T Testi & & $\mathrm{p}=, 075$ & $\mathrm{p}=, 667$ \\
\hline Yaş Dağılımı & $\mathbf{n}$ & $x \pm s s$ & $x \pm s s$ \\
\hline 15-24 yaş & 59 & $\begin{array}{c}3,61 \pm \\
, 775 \\
\end{array}$ & $\begin{array}{c}3,54 \pm \\
1,24 \\
\end{array}$ \\
\hline 25-34 yaş & 140 & $\begin{array}{c}3,33 \pm \\
, 831\end{array}$ & $\begin{array}{c}2,55 \pm \\
299 \\
\end{array}$ \\
\hline $35-44$ yaş & 144 & $\begin{array}{c}3,17 \pm \\
1,00 \\
\end{array}$ & $\begin{array}{c}2,74 \pm \\
, 431 \\
\end{array}$ \\
\hline 45 ve üzeri & 46 & $\begin{array}{c}3,26 \pm \\
, 703 \\
\end{array}$ & $\begin{array}{c}2,27 \pm \\
, 262 \\
\end{array}$ \\
\hline Anova Analizi & & $\mathrm{p}=, 015$ & $\mathrm{p}=, 000$ \\
\hline Eğitim Durumu & n & $x \pm s s$ & $x \pm s s$ \\
\hline İlköğretim & 50 & $\begin{array}{c}3,22 \pm \\
1,03 \\
\end{array}$ & $\begin{array}{c}2,64 \pm \\
, 443 \\
\end{array}$ \\
\hline Lise & 124 & $\begin{array}{c}3,33 \pm \\
, 805\end{array}$ & $\begin{array}{c}, 01 \pm \\
1,03 \\
\end{array}$ \\
\hline Önlisans & 51 & $\begin{array}{c}3,33 \pm \\
, 965\end{array}$ & $\begin{array}{c}2,58 \pm \\
299\end{array}$ \\
\hline Lisans & 143 & $\begin{array}{c}3,29 \pm \\
, 893\end{array}$ & $\begin{array}{c}2,65 \pm \\
, 393\end{array}$ \\
\hline Yüksek Lisans & 7 & $\begin{array}{c}2,96 \pm \\
1,02 \\
\end{array}$ & $\begin{array}{c}2,07 \pm \\
237\end{array}$ \\
\hline Doktora & 14 & $\begin{array}{l}3,57 \pm \\
, 753\end{array}$ & $\begin{array}{c}2,33 \pm \\
, 303\end{array}$ \\
\hline Anova Analizi & & $\mathrm{p}=, 713$ & $\mathrm{p}=, 000$ \\
\hline Çalışma Durumu & $\mathbf{n}$ & $x \pm s s$ & $x \pm s s$ \\
\hline Öğrenci & 51 & $\begin{array}{c}3,71 \pm \\
, 720\end{array}$ & $\begin{array}{c}3,72 \pm \\
1,25\end{array}$ \\
\hline Çalışıyor & 297 & $\begin{array}{c}3,26 \pm \\
, 914\end{array}$ & $\begin{array}{c}2,60 \pm \\
, 368 \\
\end{array}$ \\
\hline Çalışmıyor & 20 & $\begin{array}{c}2,99 \pm \\
, 701\end{array}$ & $\begin{array}{c}2,60 \pm \\
, 546\end{array}$ \\
\hline Emekli & 21 & $\begin{array}{c}3,24 \pm \\
, 848\end{array}$ & $\begin{array}{c}2,26 \pm \\
, 348\end{array}$ \\
\hline Anova Analizi & & $\mathrm{p}=, 003$ & $\mathrm{p}=, 000$ \\
\hline Aylık Gelir Düzeyi & $\mathbf{n}$ & $\mathrm{x} \pm \mathrm{ss}$ & $x \pm s s$ \\
\hline 550 TL'den Az & 6 & $\begin{array}{c}3,74 \pm \\
, 836\end{array}$ & $\begin{array}{l}2,62 \pm \\
, 702\end{array}$ \\
\hline $551-1000$ aras 1 & 32 & $\begin{array}{c}3,74 \pm \\
, 744 \\
\end{array}$ & $\begin{array}{c}4,39 \pm \\
1,08 \\
\end{array}$ \\
\hline $1001-1500$ arasi & 29 & $\begin{array}{c}2,90 \pm \\
, 621 \\
\end{array}$ & $\begin{array}{c}2,52 \pm \\
, 374 \\
\end{array}$ \\
\hline $1501-2000$ & 114 & $\begin{array}{c}3,50 \pm \\
, 881\end{array}$ & $\begin{array}{c}2,67 \pm \\
, 432 \\
\end{array}$ \\
\hline 2001-3000 aras1 & 119 & $\begin{array}{c}3,10 \pm \\
, 983 \\
\end{array}$ & $\begin{array}{c}2,61 \pm \\
, 354\end{array}$ \\
\hline $3001-4000$ aras1 & 58 & $\begin{array}{l}3,22 \\
, 866\end{array}$ & $\begin{array}{c}2,50 \pm \\
, 347\end{array}$ \\
\hline 4001 ve üzeri & 31 & $\begin{array}{l}3,35 \\
, 572\end{array}$ & $2,33 \pm, 244$ \\
\hline Anova Analizi & & $\mathrm{p}=, 000$ & $\mathrm{p}=, 000$ \\
\hline
\end{tabular}


"Turizm farklı toplumları temsil eden bireylerin birbirleri ile olan etkileşimini hızlandırarak yerel toplumun ekonomik ve sosyal yönden yaşam standardının artmasını sağlar" Tablo 3' de bulunan bu başlığın altındaki değişkenler incelendiğinde; turizmle başka toplum ve kültürlere sayg1 duymayı sağladığı konusunda görüş birliği içerisinde oldukları ve değişkeni destekledikleri $(x=$ $2,64)$ görülmektedir. Turizm yerel halka bir ilgi ve faaliyet alanı oluşturmaktadır noktasında kararlılık ( $x=2,34)$ içinde oldukları görülmektedir. Bu şekilde yaşamaktan memnun oldukları ( $x$ $=2,23$ ) gözlemlenmektedir. Turizmin etkisi ile Kastamonu'da sanat, el sanatları ve yerel kültürün diğer unsurları canlanmakta ve değer kazanmaktadır $(x=2,55)$, turizm sayesinde farklı kültürler hakkında yeni şeyler öğrenmek beni mutlu etmektedir $(x=2,53)$ vb. gibi konularda Kastamonu halkı kararlılıklarını devam ettirmekte olduğu görülmektedir.

\section{Araştırma Hipotezlerinin Değerlendirilmesi}

Katılımcıların demografik özellikleri ile araştırma faktörlerine yönelik algılama ve değerlendirmeleri arasında anlamlı bir ilişki var mıdır? Temel sorusu, aşağıdaki analiz de ki gibi sonuçlanmıştır:

H1: "Kadın ve erkek katılımcıların, araştırma faktörlerine yönelik algılama ve değerlendirmeleri arasında, anlamlı bir farklılık vardır" önermesi reddedilmiştir.

Erkek ve kadın katılımcıların araştırma faktörlerine yönelik algılama ve değerlendirmelerinde anlamlı bir farklılık olduğu Tablo 4'de ki bağımsız örneklem t-testi sonuçlarından anlaşılmaktadır. Bağımsız örneklem t-testi tablosunun anlamlılık (Sig.) satırındaki faktörlerin her ikisinde söz konusu baz alınan değer olan 0,05'den büyük olması, cinsiyet ile araştırma faktörlerini anlama ve değerlendirme arasında anlamlı bir ilişki olmadığını ortaya koymaktadır.

H2: "Katılımcıların araştırma faktörlerine yönelik algılama ve değerlendirmeleri yaşlarına göre bir farklılık gösterir" önermesi (Kabul)edilmiştir.

Yaş gruplarının araştırma faktörlerine ilişkin algılama ve değerlendirmeleri arasında da istatistiksel açıdan anlamlı farklılık olmadığı yapılan Varyans Analizi sonucunda belirlenmiştir. Yaş aralıklarının, birinci faktör de $(\mathrm{p}=0,015 ; \mathrm{p}<0,05)$, ikinci faktör de $(\mathrm{p}=0,000 ; \mathrm{p}<0,05)$ değerleri görülmektedir. Bu durumda yaklaşımları arasında istatistiksel olarak anlamlı bir ilişki olduğu görülmektedir.

H3: "Katılımcıların araştırma faktörlerinden birinci faktöre yönelik olumsuz yönde algılama ve değerlendirmeleri eğitim durumlarına göre bir farklılık gösterir" önermesi (Red) edilmiştir.

Kastamonu halkının araştırma faktörlerine ilişkin algılama ve değerlendirmelerinin eğitim durumlarına bağlı olarak istatistiksel açıdan faktör bir değeri $(p=0,713 ; p>0,05)$ olduğu görülmektedir. Bağımsız örneklem Tekyönlü Anova Analizi sonucunda anlamlılık (Sig.) satırındaki değerin söz konusu değer olan 0,05 'den büyük olmasından dolayı yaklaşımlar arasında istatiksel olarak anlamlı bir ilişki olmadığı görülmektedir.

H4: "Katılımcıların araştırma faktörlerinden ikinci faktöre yönelik olumlu yönde algılama ve değerlendirmeleri eğitim durumlarına göre bir farklılık gösterir" önermesi (Kabul) edilmiştir.

Kastamonu halkının araştırma faktörlerine ilişkin algılama ve değerlendirmelerinin eğitim düzeyine bağlı olarak istatistiksel açıdan faktör iki değeri $(p=0,000 ; p<0,05)$ olduğu görülmektedir. Bağımsız örneklem Tekyönlü Anova Analizi sonucunda anlamlılık (Sig.) satırındaki değerin söz konusu değer olan 0,05'den küçük olmasından dolayı yaklaşımlar arasında istatiksel olarak anlamlı bir ilişki olduğu görülmektedir. 
H5: "Katılımcıların araştırma değişkenlerine yönelik algılama ve değerlendirmeleri çalışma durumu göre bir farklılık gösterir" önermesi (Kabul) edilmiştir.

Çalışma durumlarının araştırma faktörlerine ilişkin algılama ve değerlendirmeleri arasında da istatistiksel açıdan anlamlı farklılıklar olmadığı yapılan Varyans Analizi sonucunda belirlenmiştir. Çalışma guruplarının, birinci faktör de $(\mathrm{p}=0,003 ; \mathrm{p}<0,05)$, ikinci faktör de $(\mathrm{p}=0,000$; $\mathrm{p}<0,05)$ değerleri görülmektedir. Bu durumda yaklaşımları arasında istatistiksel olarak anlamlı bir ilişki olduğu görülmektedir.

H6: "Katılımcıların araştırma değişkenlerine yönelik algılama ve aylık gelir düzeyine göre bir farklılık gösterir" önermesi (Kabul) edilmiştir.

Aylık gelir düzeyinin araştırma faktörlerine ilişkin algılama ve değerlendirmeleri arasında da istatistiksel açıdan anlamlı farklılıklar olmadığı yapılan Varyans Analizi sonucunda belirlenmiştir. Aylık gelir düzeyi, birinci faktör de $(p=0,000 ; p<0,05)$, ikinci faktör de $(p=0,000$; $\mathrm{p}<0,05)$ değerleri görülmektedir. Bu durumda yaklaşımları arasında istatistiksel olarak anlamlı bir ilişki olduğu görülmektedir.

\section{SONUÇ VE ÖNERILERR}

Turizm olgusu, yalnızca ekonomik anlamda bir aktivite olarak kalmayarak aynı zamanda sosyal, kültürel, siyasal ve coğrafi taraflarıyla da var olmayı sürdüren bir harekettir. Toplumda bulunan insanları, sosyal yapıyı etkisine alarak gerek yerel gerek ulusal ve de uluslararası alanlarda değiştirmiş ve dönüştürmüştür. Bu nedenden dolayı turizmin, ekonomik anlamda getirilerinin değerlendirmesiyle beraber, sosyal yapı ve kültürel yapı üzerinde oluşturduğu olumlu ve olumsuz etkilerinde değerlendirilmesi büyük önem taşımaktadır. Turizmin sosyal yapı ve de kültürel yapı üzerindeki etkilerinden bahsedildiğinde, ilk başta insanların birbirleri arasında kurdukları ilişkileri ve turizmin insanların üzerinde oluşturduğu etkileri göz önüne gelir. Bu ilişkilerin ve etkilerin tümü insanlar üzerinde bunun dışında çevre üzerinde, toplumun kültürü ve gelenek-görenekleri üzerinde olumlu veya olumsuz neticeler oluşturabilmektedir. Turizm hareketi bulunduğu alandaki, bölge halkına ait yaşamsal döngünün bir parçası haline gelmiştir ve yerel halkın yaşam biçimini çok yönlü ve değişkenlik gösteren sosyo-kültürel bakımdan etkileyebilmektedir.

Özellikle daha ufak yerleşim yerlerinde, sosyal yapıda ve kültürel dokuda önemli değişmeler ve etkiler gözlenmektedir Bu etkilerin aile içerisindeki iletişim kopukluğu, dini anlamda problemler, kültürel farklılaşmalar ve gelenek-görenekler üzerindeki değişimler olduğu yapılan araştırmalar sonucunda elde edilmiş bulgulardır. (Erkal, 1984: 57) Bu sebeple turizm olayının daha sürdürülebilir olması ve turizm bölgesine ait olan gelenekselleşmiş değerlerin korunabilmesi için turizmle ilgili belirlenecek önlemler ve bunun yanı sıra turizm ile ilgili alınacak kararlara yerel halkın da dâhil edilmesi, turizm bölgesine sosyo-kültürel açıdan avantajlar getirecektir.

Bu çalışma, Kastamonu İl'inde turizmin ortaya çıkardığı olumlu ve olumsuz sosyo-kültürel etkilerin, bölgede yaşayan halk tarafından nasıl algılandığı ve nasıl değerlendirildiği ile ilgilidir. Yapılan araştırma sonucunda tespit edilen bulgular şu şekilde özetlenebilir;

- Kastamonu'da ikamet edenlerin, turizmin ahlakı değerleri ve toplumsal yaşamı olumsuz etkileyip etkilemediği hususunda genel anlamda kararsız kalarak çekimser bir tutum içinde olduğu tespit edilmiştir.

- Turizm farklı toplumları temsil eden bireylerin birbirleri ile olan etkileşimini hızlandırarak yerel toplumun ekonomik ve sosyal yönden yaşam standardının artmasını sağlar noktasında yerel halkta olumsuz bir algı oluşturmadığı, yöre halkının kararlılık içerisinde olduğu gözlemlenmiştir. 
- Turizmle başka toplumlara saygı duymaya katkı sağladığı görüşüne yöre halkının sıcak bakmakta olduğu görülmüştür.

- Turizm yerel halka bir iş, ilgi ve faaliyet alanı oluşturduğu noktasında görüş birliği içerisindedirler.

- Turizmin etkisi ile Kastamonu'da sanat, el sanatları ve yerel kültürün diğer unsurları canlanmakta ve değer kazanmaktadır görüşüne katılarak kararlılık göstermişlerdir.

- Erkek ve kadın katılımcıların araştırma faktörlerine yönelik algılama ve değerlendirmelerinde anlamlı bir farklılık vardır.

- Yaş gruplarının araştırma faktörlerine ilişkin algılama ve değerlendirmeleri arasında da istatistiksel açıdan anlamlı bir farklılı̆̆ın olmadığı görülmüş̧tür.

- Kastamonu halkının araştırma faktörlerine ilişkin algılama ve değerlendirmelerinin eğitim durumuna bağlı olarak istatistiksel açıdan anlamlı farklılık gösterdiği tespit edilmiştir. Ancak turizm, farklı toplumları temsil eden bireylerin birbirleri ile olan etkileşimini hızlandırarak yerel toplumun ekonomik ve sosyal yönden yaşam standardının artmasını sağlar noktasında eğitim durumunun bu faktöre yaklaşımları arasında istatistiksel olarak anlamlılık arz ettiği, belirlenmiştir.

- Çalışma durumlarının araştırma faktörlerine ilişkin algılama ve değerlendirmeleri arasında da istatistiksel açıdan anlamlı farklılıklar olmadığı görülmüştür.

- Turizmin ahlakı değerleri bozarak toplumsal yaşamı olumsuz etkilediği konusunda çalışma durumlarının bu faktöre ilişkin farklılık göstermediği belirlenmiştir.

Araştırma sonuçlarına göre aşağıdaki öneriler geliştirilmiştir:

Kastamonu halkı genel itibariyle tam olarak turizm bilincine ulaşamamış durumdadır. Buna bağlı olarak turizme olan ilgisi düşüktür. Belirtilen sebeplerden dolayı Kastamonu halkını turizm açısından bilinçlendirmek maksadıyla halka açık ve düzenli olarak seminerler düzenlenebilir.

Halk eğitimin bünyesinde turizm ve turizmle alakalı kurslar verilerek halkın, turizme yönelmesi sağlanabilir.

Yine yapılan araştırmada Kastamonu'nun turizm açısından yeterli reklâmı yapılmadığı kanısına ulaşılmıştır. Bu konuda çalışmalar yürütülebilir.

\section{KAYNAKÇA}

Alaeddinoğlu, F. (2008). Sivas Kentinde Halkın Turiste ve Turizme Bakışı, Uluslararası İnsan Bilimleri Dergisi, 5(2), 1-23.

Avcı, M. (2019). Hedef-2019, Vuslatını 450. Yıldönümünde, Hz. Pir Şeyh Şaban-I Veli Yılı (Fikri, teklifi ve çabası serüveni), Kastamonu.

Avcıkurt, C. (2009). Turizm Sosyolojisi Genel ve Yapısal Yaklaşım. Ankara: Detay Yayıncılık

Demircan, Ş. (2011). Turizmde 2. İnsan Kaynakları Gelişimi Sempozyumu Bildiri Kitabı. Ankara: Mattek Matbaacilik.

Doğal Hayatı Koruma Vakfı, (2000). Doğadaki Ayak İzlerimiz, Türkiye Doğal Hayatı Koruma Derneği/ Doğal Hayatı Koruma Vakfı, İstanbul.

Doğan, H. Z. (1987). Turizmin Sosyo Kültürel Temelleri. İzmir: Uğur Ofset Matbaacllık ve Ticaret.

Doğan, H. Z. (2004). Turizmin Sosyo Kültürel Temelleri. Ankara: Detay Yayıncllı. 
Erdoğan, H. (1995). Ekonomik Sosyo-Kültürel Çevresel Yönleriyle Uluslararası Turizm. Uludă̆ Üniversitesi Yaymları, 18, 003-0275.

Erkal, M. (1984). Sosyal Meselelerimiz ve Sosyal Değişme. Ankara: Mayaş Yayınları.

Gümüş, N. ve Özüpekçe, S. (2009). Foça'da Turizmin Ekonomik, Sosyal, Kültürel ve Çevresel, Etkilerine Yönelik Yerel Halkın Görüşleri, Uluslararası İnsan Bilimleri Dergisi, 6(2), 398-417.

Güney, E. (1992). Çevre Sorunları. 2.Baskı. Ankara: Hatipoğlu Yayınları.

Gürbüz, A. (2002). Turizmin Sosyal Çevreye Etkisi Üzerine Bir Araştırma, Teknoloji Dergisi, 1(2), 49-59.

İlkin, A. ve Dinçer, M. Z. (1991). Turizm Türk Ekonomisindeki Yeri ve Önemi, Ekonomik ve Sosyal Sorunlar- Çözüm Önerileri Dizisi, TOBB.

İncekara, A. (2001). Anadolu'da Yeni Turizm Olanakları ve Bölgesel Kalkınmadaki Yeri. İstanbul: İstanbul Ticaret Odası, Yayın No: 2001-28.

Kastamonu Valiliği, (2018). Kastamonu: İl Kültür ve Turizm Müdürlüğü.

Kastamonu Belediyesi, (2018). Kastamonu Gezi Rehberi.

Kastamonu Valiliği, (2018). Kastamonu Kültür Envanteri - I. (Merkez). Kastamonu: İl Kültür ve Turizm Müdürlüğü-Müze Müdürlüğü.

Kozak, N., Akoğlan Kozak, M., ve Kozak, M. (2001). Genel Turizm Illkeleri- Kavramlar. Ankara: Detay Yayıncilık.

Kuzey Anadolu Kalkınama Ajansı, (2018). Kastamonu, Türk Dünyası Kültür Başkenti-Kastamonu 2018. Kastamonu: KUZKA Yayını.

Mansuroğlu, S. (2006). Turizmin Gelişmelerine Yerel Halkın Yaklaşımlarının Belirlenmesi: Akseki/Antalya Örneği. Akdeniz Üniversitesi Ziraat Fakültesi Dergisi, 19(1), 35-46.

Olalı, H. (1990). Turizm Politikası ve Planlaması. İstanbul: Yön Ajans.

Öncü, M. A., Güney, İ ve Göközkut, B. (2018). Ilgaz Dağı Milli Parkı ve Kış Sporları Turizm Merkezinin Sürdürülebilirlik Kriterlerine Göre Değerlendirilmesi, Uluslararası Sosyal Araştırmalar Dergisi, 11(59).

Özgüç, N. (1984). Turizm Coğrafyası. İstanbul: Güryat Matbaacilık.

Sarı, Y. (2014). Turizm ve Ekonomik Çevre, (Editörler) Özdipçiner, N. S. ve Ayazlar, G.: Genel Turizm içinde. İstanbul: Lisans Yayıncılık.

Sayım, F. (2017). Sosyal Bilimlerde Araştırma ve Tez Yazma Yöntemleri. Ankara: Seçkin Yayıncılık.

Seçilmiş, C. (2014). Turizmde Fiziksel ve Sosyo-Kültürel Çevre, (Editörler) Özdipçiner, N. S. ve Ayazlar, G.: Genel Turizm içinde. İstanbul: Lisans Yayıncılık.

Türksoy. (2018). 2018 Türk Dünyası Kültür Başkenti Kastamonu. [Çevirimiçi] https://www.turksoy.org/tr/news/2017/12/05/2018-turk-dunyasi-kultur-baskenti-kastamonu [Erişim tarihi: 01.11.2019].

Uslu, A., ve Kiper, T. (2006). Turizmin Kültürel Miras Üzerine Etkileri: Beypazarı/Ankara Örneğinde Yerel Halkın Farkındalığı, Tekirdağ Ziraat Fakültesi Dergisi, 3(3), 305-314. 